\title{
The effects of professional ethics and commitment on audit quality
}

\author{
Aliasghar Nasrabadi ${ }^{\mathrm{a}}$ and Aliakbar Arbabian ${ }^{\mathrm{b}^{*}}$
}

${ }^{a}$ Master's Student, Department of Accounting, Damavand Science and Research Branch, Islamic Azad University, Damavand, Iran ${ }^{b}$ Faculty Member, Department of Management and Accounting, Shahid Beheshti University, Tehran, Iran

\section{H R O N I C L E}

\begin{tabular}{l}
\hline Article history: \\
Received March 25, 2015 \\
Received in revised format \\
August 62015 \\
Accepted August 172015 \\
Available online \\
August 182015 \\
\hline Keywords: \\
Audit quality \\
Professional ethics \\
Commitment \\
Tehran Stock Exchange \\
\hline
\end{tabular}
\begin{abstract}
A B S T R A C T
This paper presents a study on the effects of professional ethics and commitments on audit quality. The population of this survey includes all audit managers who were active in auditing official statements of different firms listed in Tehran Stock Exchange in 2014. The study designs a questionnaire in Likert scale and distributes it among 152 randomly selected managers. In our survey, professional ethics consists of four items including confidentiality and impartiality, professional competence, accountability and individual values while organizational commitment consists of three items including emotional commitment, continues commitment and fundamental commitment. Using Pearson correlation as well as regression models, the study has determined a positive and meaningful relationship between professional ethics as well as commitment and audit quality.
\end{abstract}

\section{Introduction}

In recent years, there has been growing interest on learning the effects of different variables on audit quality (Cullen et al., 1993; Sun \& Liu, 2012; Zadek et al., 2013). Gendron et al. (2006) explored the relationship between work context and professional ethics by performing an online survey of professional accountants the degree to which changing work conditions could possibly alter individual accountants' commitment to the core professional value of auditor independence. They argued that some changes in the condition of work could make some categories of accountants more susceptible to the idea of commercialism rather than the idea of professionalism. They reported that accountants working outside of public accounting had a bigger commitment to independence than do accountants working in the context of public accounting companies. They also detected that accountants in large international accounting companies report lower commitment to auditor independence than public accounting did. In addition, they reported that older accountants reported bigger commitment to auditor independence. Nevertheless, they found that commitment to one's client could not necessarily yield in a loss of commitment to the core professional value of independence and concluded that changes in the context of work could possibly contribute to the demise of ethics among professional accountants and

\footnotetext{
* Corresponding author. Tel: +98-9121343019

E-mail address: arbabian2007@yahoo.com (A. Arbabian) 
recommended that further research be accomplished to elaborate the relationship between client commitment and independence commitment.

Jackling et al. (2007) examined the significance of ethical issues, which could possibly challenge the profession and, more specifically, professional accounting bodies and identified a number of important challenges including conflicts of interest, earnings management and whistle-blowing. They also reported strong support for taking part in prescribing the nature of ethics education by members of professional accounting bodies. Elias (2008) examined the attitude of 128 US auditing students regarding whistleblowing and reported that auditing students with more commitment to their profession and higher perception of financial reporting were more likely to blow the whistle on illegal management actions.

Shafer (2009) concentrated on the impacts of the ethical climate in Chinese certified public accounting (CPA) companies on auditors' perceptions of organizational-professional conflict (OPC) and affective organizational commitment (OC). They also examined for differences in the perceived ethical climates of local and international CPA companies. They determined certain dimensions of the perceived ethical climate were substantially associated with OPC, and to affective OC. In addition, they found a strong negative relationship between OPC and OC but reported no clear pattern of differences in the perceived ethical climates in local and international CPA companies. Moreover, impression management was highly related to OPC, OC, and three of four ethical climate dimensions, recommending that Chinese auditors bias their reports of these variables in a socially desirable fashion.

Kosmala and Herrbach (2006) explored how identity could be self-managed in professional services firms, demonstrated by the Big Four audit firms. They investigated both identification and distancing processes with several identity attributes of professionalism, viewed as outcomes of technologies of the self. They argued that the ambivalence inherent in these attributes enable auditors to cynically distance themselves from the regulatory structures of their environment. Herrbach (2001) used a model based on 'psychological contract' assessment and affective commitment to study for audit quality reduction attitudes by the respondents. They reported that the psychological contract elements dealing with the professional aspect of auditing were the most influential, and that affective commitment was correlated to social but not to technical quality reduction behaviours. Chun et al. (2013) highlighted the need to study microprocesses happening within the firm to account for the ethics-firm performance relationship.

\section{The proposed study}

This paper presents a study on the effects of professional ethics and commitments on audit quality (Deis Jr, \& Giroux, 1992). The population of this survey includes all audit managers who were active in auditing official statements of different firms listed in Tehran Stock Exchange in 2014. The study designs a questionnaire in Likert scale and distributes it among some randomly selected managers. The sample size in our survey is calculated as follows,

$$
n=\frac{N \times z_{\alpha / 2}^{2} \times p \times q}{\varepsilon^{2} \times(N-1)+z_{\alpha / 2}^{2} \times p \times q},
$$

where $N$ is the population size, $p=1-q$ represents the yes/no categories, $z_{\alpha / 2}$ is CDF of normal distribution and finally $\varepsilon$ is the error term. Since we have $p=0.5, z_{\alpha / 2}=1.96$ and $N=244$, the number of sample size is calculated as $n=152$. There are two main hypotheses with the propsoed study as follows, 


\subsection{Main hypothesis}

1. There is a meaningful relationship between professional ethics and quality of auditing.

2. There is a meaningful relationship between organizational commitment and quality of auditing.

\subsection{Sub-hypotheses}

There are also seven sub-hypotheses associated with the proposed study of this paper as follows,

1. There is a meaningful relationship between confidentiality as well as impartiality and quality of auditing.

2. There is a meaningful relationship between professional competence and quality of auditing.

3. There is a meaningful relationship between accountability and quality of auditing.

4. There is a meaningful relationship between individual values and quality of auditing.

5. There is a meaningful relationship between emotional commitment (Duckett \& Macfarlane, 2003) and quality of auditing.

6. There is a meaningful relationship between continues commitment and quality of auditing.

7. There is a meaningful relationship between fundamental commitment and quality of auditing.

Fig. 1 shows details of the proposed study of this paper.

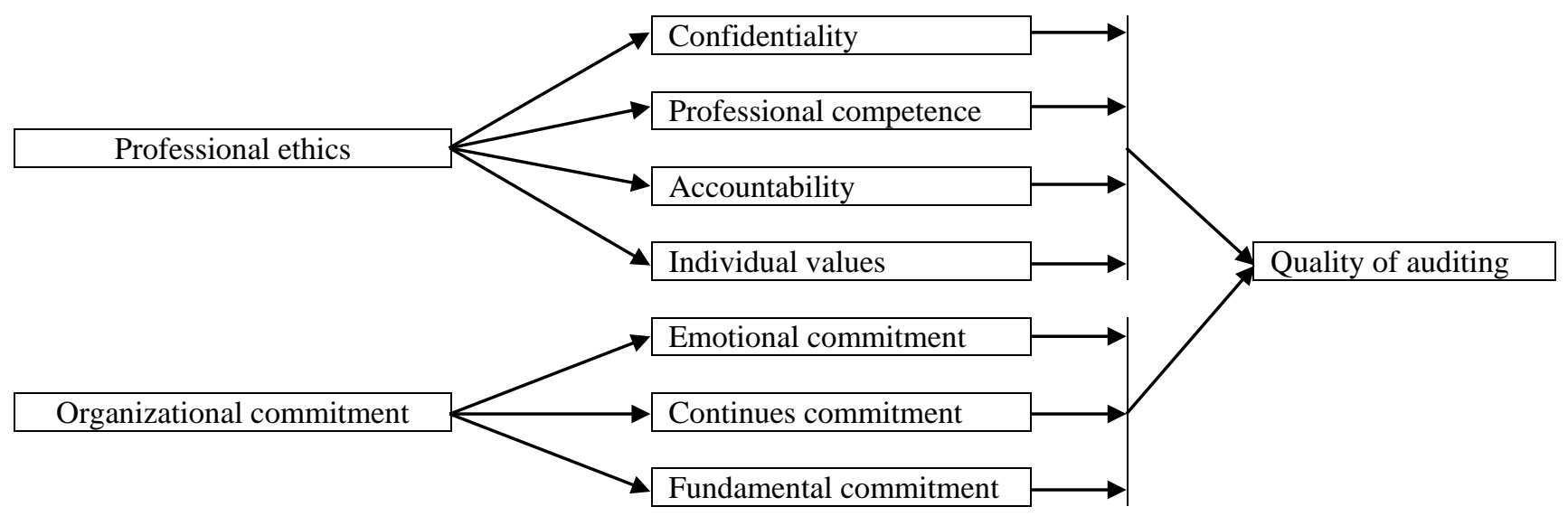

Fig. 1. The structure of the proposed study

The questionnaire was designed in Likert scale and it was distributed among some experts and they confirmed the overall questionnaire of the survey. In addition, the calculated Cronbach alpha were well above the minimum acceptable level of 0.7. Therefore, the overall questionnaire has been verified. Also, Kolmogorov-Smirnov test has indicated that all components of the survey were normally distributed.

\section{The results}

In this section, we present the implementation of Pearson correlation as well as regression technique to example two main hypotheses as well as seven sub-hypotheses of the survey.

\subsection{The first main hypothesis: The relationship between professional ethics and quality of auditing}

The first main hypothesis of this survey investigates the relationship between professional ethics (PE) and quality of auditing (QA). 


$$
Q A=-21.57+0.167 P E
$$

t-value $7.12 \quad 5.35$ Adj. R-Square $=0.155$ Durbin-Watson $=1.96$

Sig. $\quad 0.01 \quad 0.01$ F-value $=28.66$ Sig. $=0.00 \quad r=0.401$ Sig. $=0.000$

As we can observe from the results of regression analysis, F-value is statistically significant, which means there is a linear relationship between independent and dependent variable. Adjusted R-Square indicates that the independent variable describes approximately $16 \%$ of the changes of dependent variable. Pearson correlation ratio also indicates that there is a positive correlation between two variables. T-student value is also statistically significant, which confirms the first hypothesis of the survey.

\subsubsection{The relationship between components of professional ethics with audit quality}

The implementation of the regression technique on measuring the relationship between components of professional ethics with audit quality. Table 1 demonstrates the results of our survey.

\section{Table 1}

The results of regression analysis between components of professional ethics and audit quality

\begin{tabular}{lccccc}
\hline Variable & $\beta$ & Non-standard value & Standard value & t-value & Sig. \\
\hline Intercept & 17.42 & 3.28 & & 5.29 & 0.001 \\
Confidentiality & 0.327 & 0.058 & 0.424 & 5.61 & 0.001 \\
Competency & 0.381 & 0.188 & 0.157 & 2.03 & 0.044 \\
Accountability & 0.233 & 0.107 & 0.169 & 2.18 & 0.030 \\
Individual values & -0.230 & 0.145 & -0.117 & 1.58 & 0.144 \\
\hline
\end{tabular}

Adj-R-Square $=0.294 \quad$ F-value $=16.73($ Sig. $=0.000)$ Durbin-Watson $=1.97$

As we can observe from the results of regression analysis, F-value is statistically significant, which means there is a linear relationship between independent and dependent variable. Adjusted R-Square shows that the independent variable describes approximately $30 \%$ of the changes of dependent variables. The effects of confidentiality, competency and accountability are statistically meaningful when the level of significance is five percent. However, the effect of individual values is not statistically significant. Therefore there are some positive and meaningful relationship between audit quality and three independent variables; namely confidentiality, competency and accountability.

3.2.The second main hypothesis: The relationship between organizational commitment and audit quality

The second hypothesis of this survey investigates the relationship between organizational commitment (OC) and audit quality (AQ). The results of regression analysis is as follows,

$$
A Q=29.56+0.168 O C
$$

t-value 22.676 .38 Adj. R-Square $=0.214$ Durbin-Watson $=1.97$

Sig. $\quad 0.01 \quad 0.01 \mathrm{~F}$-value $=40.78$ Sig. $=0.00 \mathrm{r}=0.462$ Sig. $=0.000$

As we can observe from the results of regression analysis, F-value is statistically significant, which means there is a linear relationship between independent and dependent variable. Adjusted R-Square indicates that the independent variable describes approximately $21 \%$ of the changes of dependent variable. Pearson correlation ratio also indicates that there is a positive correlation between two variables. T-student value is also statistically significant, which confirms the second hypothesis of the survey. 


\subsubsection{The relationship between components of organizational commitment with audit quality}

The implementation of the regression technique on measuring the relationship between components of organizational commitment with audit quality. Table 2 demonstrates the results of our survey.

\section{Table 2}

The results of regression analysis between components of organizational commitment and audit quality

\begin{tabular}{lccccc}
\hline Variable & $\beta$ & Non-standard value & Standard value & t-value & Sig. \\
\hline Intercept & 25.88 & 1.824 & & 14.18 & 0.001 \\
Emotional & -0.099 & 0.092 & -0.089 & -1.07 & 0.286 \\
Continuous & 0.464 & 0.109 & 0.368 & 4.27 & 0.001 \\
Fundamental & 0.326 & 0.089 & 0.291 & 3.68 & 0.001 \\
\hline
\end{tabular}

Adj-R-Square $=0.261 \quad$ F-value $=18.81($ Sig. $=0.001)$ Durbin-Watson $=1.98$

As we can observe from the results of regression analysis, F-value is statistically significant, which means there is a linear relationship between independent and dependent variable. Adjusted R-Square shows that the independent variable describes approximately $26 \%$ of the changes of dependent variables. The effects of continuous commitment and fundamental commitment are statistically meaningful when the level of significance is one percent. However, the effect of emotional commitment is not statistically significant. Therefore there are some positive and meaningful relationship between audit quality and two independent variables; namely continuous as well as fundamental commitments.

\section{Conclusion}

In this paper, we have presented an empirical investigation to study the effects of professional ethics and commitments on audit quality. Using regression analysis, the study has detected a positive and meaningful relationship professional ethics with audit quality $(\beta=0.167$, Sig. $=0.001)$. The effects of continuous commitment and fundamental commitment are statistically meaningful when the level of significance is one percent. However, the effect of emotional commitment is not statistically significant. In addition, there was a meaningful relationship between organizational commitment and audit quality $(\beta=0.168$, Sig. $=0.001)$. The effects of continuous commitment and fundamental commitment are statistically meaningful when the level of significance is one percent. However, the effect of emotional commitment is not statistically significant.

\section{Acknowledgement}

The authors would like to thank the anonymous referees for constructive comments on earlier version of this paper.

\section{References}

Cullen, J. B., Victor, B., \& Bronson, J. W. (1993). The ethical climate questionnaire: An assessment of its development and validity. Psychological reports, 73(2), 667-674.

Chun, J. S., Shin, Y., Choi, J. N., \& Kim, M. S. (2013). How does corporate ethics contribute to firm financial performance? The mediating role of collective organizational commitment and organizational citizenship behavior. Journal of Management, 39(4), 853-877.

Deis Jr, D. R., \& Giroux, G. A. (1992). Determinants of audit quality in the public sector. Accounting Review, 67(3), 462-479.

Duckett, H., \& Macfarlane, E. (2003). Emotional intelligence and transformational leadership in retailing. Leadership \& Organization Development Journal, 24(6), 309-317.

Elias, R. (2008). Auditing students' professional commitment and anticipatory socialization and their relationship to whistleblowing. Managerial Auditing Journal, 23(3), 283-294. 
Gendron, Y., Suddaby, R., \& Lam, H. (2006). An examination of the ethical commitment of professional accountants to auditor independence. Journal of Business Ethics, 64(2), 169-193.

Herrbach, O. (2001). Audit quality, auditor behaviour and the psychological contract. European Accounting Review, 10(4), 787-802.

Jackling, B., Cooper, B. J., Leung, P., \& Dellaportas, S. (2007). Professional accounting bodies' perceptions of ethical issues, causes of ethical failure and ethics education. Managerial Auditing Journal, 22(9), 928-944.

Kosmala, K., \& Herrbach, O. (2006). The ambivalence of professional identity: On cynicism and jouissance in audit firms. Human relations, 59(10), 1393-1428.

Shafer, W. E. (2009). Ethical climate, organizational-professional conflict and organizational commitment: A study of Chinese auditors. Accounting, Auditing \& Accountability Journal, 22(7), 1087-1110.

Sun, J., \& Liu, G. (2012). Auditor industry specialization, board governance, and earnings management. Managerial Auditing Journal, 28(1), 45-64.

Zadek, S., Evans, R., \& Pruzan, P. (2013). Building corporate accountability: Emerging practice in social and ethical accounting and auditing. Routledge. 